\title{
Potential of Actinomycetes Isolates as Antimicrobials for Salmonella typhi
}

\author{
Hilwah $^{1 *}$, Meiskha Bahar ${ }^{2}$, Andri Pramesyanti Pramono ${ }^{2}$ \\ ${ }^{1}$ Program Studi Sarjana Kedokteran, Fakultas Kedokteran, Universitas Pembangunan Nasional Veteran Jakarta, Jl. \\ R.S. Fatmawati No 1, Jakarta Selatan 12450, Indonesia \\ ${ }^{2}$ Departemen Mikrobiologi, Fakultas Kedokteran, Universitas Pembangunan Nasional Veteran Jakarta, Jl. R.S. \\ Fatmawati No. 1, Jakarta Selatan 12450, Indonesia \\ *Corresponding author: hilwahzimah@gmail.com
}

\begin{abstract}
Actinomycetes are aerobic bacteria and Gram-positive bacilli. Acinomycets have an antimicrobial, antitumor, immunosuppressive, and antiparasitic acivity. This study aims to determine the antimicrobial potency of Actinomycetes against Salmonella typhi. The research design was a true experimental design with Actinomycetes isolates obtained from the Microbiology Laboratory of the Veteran National Development University, Jakarta. Rejuvenation of Actinomycetes isolates used spread plate method on media Starch Casein Agar (SCA) with six serial dilutions of $10^{-1}, 10^{-2}, 10^{-3}$, $10^{-4}, 10^{-5}$, and $10^{-6}$. The antimicrobial test method used the liquid dilution method to determine the value of the minimum inhibitory concentration (MIC) with Trypticase Soy Broth (TSB) media followed by colony calculations on Salmonella Shigella Agar (SSA) media to determine the value of the minimum bactericidal concentration (MBC). The results showed that the antimicrobial activity of Actinomycetes isolates is bacteriostatic with MIC value of $10^{-2}$. MBC value cannot be determined. It can be concluded that there is a potential of Actinomycetes isolates as an antimicrobial against Salmonella typhi $(\mathrm{p}<0.05)$.
\end{abstract}

Keywords : Actinomycetes, antimicrobe, Salmonella typhi

\section{ABSTRAK}

Actinomycetes adalah bakteri aerob, basil Gram positif dengan kencenderungan membentuk filamen. Actinomycetes memiliki aktivitas antimikroba, antitumor, imunosupresif, dan antiparasit. Penelitian ini bertujuan untuk mengetahui potensi antimikroba isolat Actinomycetes yang berasal dari Kebun Raya Bogor terhadap pertumbuhan bakteri Salmonella typhi. Desain penelitian menggunakan desain eksperimental dengan isolat Actinomycetes yang terdapat di Laboratorium Mikrobiologi Universitas Pembangunan Nasional Veteran Jakarta. Peremajaan isolat Actinomycetes menggunakan metode spread plate pada media Starch Casein Agar (SCA) dengan enam seri pengenceran $10^{-1}, 10^{-2}, 10^{-3}, 10^{-4}, 10^{-5}$, dan $10^{-6}$. Metode uji antimikroba menggunakan metode dilusi cair untuk mengetahui nilai konsentrasi hambat minimum (KHM) dengan media Trypticase Soy Broth (TSB) dan dilanjutkan perhitungan koloni pada media Salmonella Shigella Agar (SSA) untuk mengetahui nilai konsentrasi bunuh minimum (KBM). Nilai KHM didapatkan pada konsentrasi isolat Actinomycetes $10^{-2}$. Aktivitas antibakteri isolat Actinomycetes adalah bakteriostatik. Nilai KBM tidak dapat ditentukan. Isolat Actinomycetes memiliki potensi antimikroba yang bermakna terhadap Salmonella typhi $(\mathrm{p}<0,05)$.

Kata Kunci : Actinomycetes, antimikroba, Salmonella typhi 


\section{PENDAHULUAN}

Penyakit infeksius adalah penyakit yang disebabkan oleh mikroorganisme seperti virus, bakteri, dan jamur yang menginfeksi tubuh. Penyakit infeksius dapat menular secara langsung dengan cara menyebar dari satu orang ke orang lainnya, melalui zat-zat seperti air, makanan, dan tanah yang terkontaminasi atau pun dibawa oleh suatu vektor [1].

Demam tifoid merupakan penyakit infeksius yang mengancam jiwa, disebabkan oleh bakteri Salmonella typhi. World Health Organization, pada tahun 2018, mengestimasi 11-20 juta orang di dunia terdiagnosis demam tifoid, dengan 128.000-161.000 orang meninggal tiap tahunnya. Di Indonesia, diperkirakan 800100.000 orang terdiagnosis demam tifoid setiap tahun. Demam tifoid patut diperhatikan oleh berbagai pihak, karena penyakit ini bersifat endemik di Indonesia [2].

Penyebab utama demam tifoid, S. typhi, merupakan bakteri dari spesies Salmonella. Meningkatnya jumlah kasus resistensi $S$. typhi terhadap obat-obatan terus berkembang [3]. Asia Selatan dan Asia Tenggara memiliki prevalensi resistensi $S$. typhi yang tinggi karena terjadi luasnya konsumsi beberapa kelas antibiotik [4].

Sumber produksi antibiotik dapat dieksplorasi dari metabolit sekunder suatu mikroorganisme yang berasal dari tanah. Salah satu contohnya adalah Actinomycetes. Actinomycetes adalah bakteri aerob grup besar dan beragam, basil Gram positif dengan kencenderungan membentuk rantai atau filamen [5]. Actinomycetes merupakan mikroorganisme yang memiliki peran penting mengingat metabolit sekundernya kaya akan manfaat, seperti antibiotik, antitumor, imunosupresif, antiparasit, dan lain-lain [6].

Telah banyak penelitian dilakukan untuk mengetahui potensi antibakteri Actinomycetes. Charousova dkk pada tahun 2017 mengukur aktivitas antimikroba 66 isolat Actinomycetes, 42 diantaranya memiliki potensi antimikroba. Identifikasi dilakukan dan didapatkan spesies Streptomyces scabrisporus, Streptomyces sparsogenes, Streptomyces misakiensis, Streptomyces cirratus, Streptomyces lincolnensis, Streptomyces endophyticus, Streptomyces chartreusis, dan Streptomyces alboniger memiliki aktivitas antimikroba dengan spektrum luas [7]. Bahar pada tahun 2018 melalukan penelitian mengenai efek isolat Actinomycetes terhadap aktivitas proteolitik dan amiolitik Escherichia coli ATTC 25922. Penelitian tersebut menunjukkan hasil yaitu terdapat senyawa inhibitor terhadap enzim protease dan amilase E. coli ATTC 25922 [7]. Penelitian dilakukan Tiara pada tahun 2017, menguji efektivitas isolat Actinomycetes dengan metode difusi. Penelitian tersebut mendapatkan hasil semakin tinggi konsentrasi isolat Actinomycetes maka semakin kecil ukuran zona bening yang terbentuk [8]. Penelitian lain dilakukan oleh Suryani dkk pada tahun 2014, menilai potensi antimikroba Actinomycetes yang diisolasi dari tanah gambut Desa Rimbo Panjang, Kabupaten Kampar Riau, terhadap pertumbuhan bakteri Escherichia coli dan Salmonella typhi. Uji antibakteri pada penelitian tersebut menggunakan metode agar disk. Hasil dari penelitian tersebut adalah dari jumlah isolat sebanyak 24 isolat, terdapat sepuluh isolat dapat menekan pertumbuhan $E$. coli dan 16 isolat dapat menekan pertumbuhan S. typhi [9].

Sementara itu, Fatah pada tahun 2013 menemukan bahwa 43 isolat Actinomycetes yang diambil dari tanah sawah yang ditanami padi jenis joe apu dari daerah Sukoharjo tidak memiliki daya hambat terhadap pertumbuhan bekteri S. typhi [10].

Berdasarkan beberapa penelitian tersebut di atas, didapatkan kesimpulan yang berbeda-beda mengenai aktivitas antibakteri isolat Actinomycetes terhadap $S$. typhi. Penelitian ini dilakukan untuk mengetahui potensi antimikroba isolat Actinomycetes terhadap bakteri S. typhi. Isolat Actinomycetes yang digunakan pada penelitian ini berasal dari tempat yang berbeda yaitu berasal dari Kebun Raya Bogor. 


\section{METODE PENELITIAN}

\section{Desain penelitian}

Jenis penelitian yang digunakan pada penelitian ini adalah studi eksperimental yaitu true experimental dengan desain posttest-only control group, untuk menilai potensi isolat Actinomycetes sebagai antibakteri terhadap Salmonella typhi.Penelitan ini menggunakan metode dilusi cair dan dilanjutkan dengan perhitungan koloni pada cawan padat.

Penelitian ini memiliki delapan kelompok sampel yaitu isolat Actinomycetes dengan enam konsentrasi berbeda $\left(10^{-1} ; 10^{-2} ; 10^{-}\right.$ ${ }^{3} ; 10^{-4} ; 10^{-5} ; 10^{-6}$ ), kontrol positif, dan kontrol negatif yaitu akuades.Berdasarkan perhitungan menggunakan rumus Federer, didapatkan hasil pengulangan untuk tiap kelompok eksperimen adalah tiga kali.

Data pada penelitian ini disajikan secara deskriptif dan analitik.Data Konsentrasi Hambat Minimum (KHM) dan Konsentrasi Bunuh Minimum (KBM) disajikan secara deskriptif. Selanjutnya, data hasil perhitungan jumlah koloni yang tumbuh pada media SSA akan dianalisis dengan metode analitik Uji One-Way ANOVA dan uji post-hoc.

\section{Bahan penelitian}

Bahan utama dalam penelitian ini adalah sampel isolat Actinomycetesdan sampel bakteri Salmonella typhi. Media pertumbuhan bakteri yang digunakan adalah media Starch Casein Agar (SCA), media Trypticase Soy Broth (TSB), media Salmonella Shigella Agar (SSA).

\section{Peremajaan isolatActinomycetes}

Peremajaan Actinomycetes dilakukan dengan cara mengambil satu ose bulat koloni Actinomycetes dari media SCA lama, lalu ditanam di media SCA baru. Selanjutnya, inkubasi Actinomycetes pada media SCA baru tersebut selama tujuh hari.

\section{Identifikasi makroskopik Actinomycetes}

Identifikasi makroskopik dilakukan dengan menilai koloni yang tumbuh pada media SCA setelah dilakukan peremajaan.

\section{Identifikasi mikroskopik Actinomycetes}

Identifikasi mikroskopik dilakukan dengan pewarnaan Gram.Kemudian identifikasi dilakukandengan mikroskop.

\section{Pembuatan suspensi bakteri}

Bakteri Salmonella typhi pada media yang sudah mengeras diambil satu ose, lalu dicampurkan ke dalam larutan $\mathrm{NaCl}$ 0,9\%. Selanjutnya, kekeruhan yang timbul disesuaikan dengan standar kekeruhan Mc. Farland 0,5 (konsentrasi $10^{8} \mathrm{CFU} / \mathrm{mL}$ ). Lalu, suspensi bakteri diambil sebanyak $0,1 \mathrm{ml}$ menggunakan mikropipet dan diinokulasikan pada media SSA dengan metode tuang (pour plate).

\section{Pengenceran isolat Actinomycetes}

Isolat Actinomycetes pada media SCA diambil satu ose, lalu dilarutkan ke dalam meda TSB. Selanjutnya, kekeruhan yang timbul disesuaikan dengan standar kekeruhan 0,5 Mc. Farland. Setelah itu, dilakukan pengenceran dengan mengambil $1 \mathrm{ml}$ suspensi isolat Actinomycetes yang dicampurkan ke media TSB baru.Pengenceran dilakukan sampai dengan konsentrasi $10^{-6}$.

\section{Pengukuran aktivitas antibakteri}

Pengukuran aktivitas antibakteri isolat Actinomycetes dilakukan dengan mengambil isolat Actinomycetes dengan enam konsentrasi berbeda $\left(10^{-1} ; 10^{-2} ; 10^{-3} ; 10^{-4} ; 10^{-5} ; 10^{-6}\right)$ masing-masing satu ose lalu dimasukkan ke media TSB yang berbeda bersama $1 \mathrm{ml}$ suspensi S. typhi. Selanjutnya dilakukan inkubasi selama 24 jam, lalu menilai derajat kekeruhannya untuk mendapatkan Konsentrasi Hambat Minimum (KHM).

Kemudian, suspensi dalam tabung pengujian KHM dipindahkan ke media SSA dan diinkubasi 24 jam untuk menghitung koloni S. typhi dengan metode Standard Plate Count (SPC). Dari hasil perhitungan tersebut, Konsentrasi Bunuh Minimum (KBM) ditentukan. Percobaan tersebut dilakukan dengan tiga kali pengulangan. Lalu, menarik kesimpulan dan saran. 


\section{HASIL PENELITIAN}

\section{Identifikasi isolat Actinomycetes}

Tabel 1 menunjukkan hasil identifikasi isolat Actinomycetes.Identifikasi makroskopik dilakukan dengan pengamatan koloni bakteri yang tumbuh pada media selektif untuk isolasi Actinomycetes yaitu media Starch Casein Agar (SCA).Identifikasi mikroskopik dilakukan dengan cara pewarnaan Gram.

Hasil pengamatan pada hari ke tujuh inkubasi dengan suhu $37^{\circ} \mathrm{C}$, ditemukan tumbuhnya koloni bubuk dan kasar yang berwarna putih kekuningan dan anyaman miselium halus dengan aroma khas isolat Actinomycetes.

Hasil pengamatan pada mikroskop, tampak morfologi Actinomycetes yang memiliki sel berbentuk batang, susunan membentuk rantai dengan cabang, dan berwarna ungu (Gram positif).

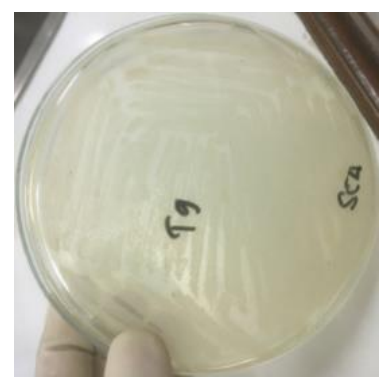

Gambar 1. Actinomycetes pada Media SCA

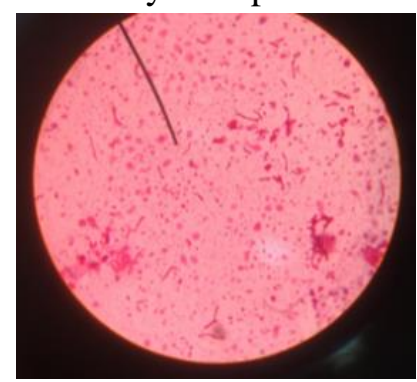

Gambar 2. Actinomycetes pada Pewarnaan Gram

Tabel 1. Identifikasi Isolat Actinomycetes

\begin{tabular}{cc}
\hline Identifikasi & Hasil Pengamatan \\
\hline Makroskopik & \\
Bentuk & Koloni bubuk dan kasar dengan anyaman miselium \\
Warna & Putih kekuningan \\
Aroma & Khas isolat Actinomycetes \\
Mikroskopik & \\
Bentuk & Batang panjang \\
Susunan & Tunggal dengan cabang \\
Warna & Ungu \\
Sifat & Gram positif \\
Metode & Pewarnaan Gram \\
\hline
\end{tabular}

Konsentrasi hambat minimum isolat Actinomycetes terhadap Salmonella typhi

Tabel 2 menunjukkan hasil pengamatan tabung uji isolat Actinomycetes dari konsentrasi $10^{-1}$ hingga $10^{-6}$ masih menunjukkan adanya kekeruhan. Kekeruhan tersebut menunjukkan masih adanya pertumbuhan bakteri $S$. typhi. Tabung uji kontrol positif, berisi kloramfenikol, tidak menunjukkan adanya kekeruhan. Selanjutnya pada tabung uji kontrol negatif, berisi akuades, menunjukkan adanya kekeruhan karena pada tabung tersebut karena tidak ada substansi yang dapat menghambat pertumbuhan bakteri S. typhi.

Berdasarkan hasil pengamatan kekeruhan pada tabung uji, nilai KHM isolat Actinomycetes dalam menghambat pertumbuhan bakteri $S$. typhi tidak dapat ditentukan karena masih adanya kekeruhan pada ke-enam konsentrasi isolat Actinomycetes. 
Tabel 2. Konsentrasi Hambat Minimum pada Tabung Uji

\begin{tabular}{ccccccccc}
\hline \multicolumn{8}{c}{ Kekeruhan pada Tabung Uji } \\
\hline Percobaan & $10^{-1}$ & $10^{-2}$ & $10^{-3}$ & $10^{-4}$ & $10^{-5}$ & $10^{-6}$ & Kontrol $(+)$ & Kontrol (-) \\
\hline 1 & Keruh & Keruh & Keruh & Keruh & Keruh & Keruh & Bening & Keruh \\
2 & Keruh & Keruh & Keruh & Keruh & Keruh & Keruh & Bening & Keruh \\
3 & Keruh & Keruh & Keruh & Keruh & Keruh & Keruh & Bening & Keruh \\
\hline
\end{tabular}

Konsentrasi bunuh minimum isolat Actinomycetes terhadap Salmonella typhi

Nilai KBM dilakukan dengan cara perhitungan koloni $S$. typhi pada media SSA. Perhitungan jumlah koloni $S$. typhi dilakukan dengan waktu inkubasi 24 jam dan 48 jam.

Tabel 3 menunjukkan hasil perhitungan koloni $S$. typhi pada media SSA dengan waktu inkubasi 24 jam yang selanjutnya akan digunakan untuk menentukan KBM isolat Actinomycetes terhadap pertumbuhan bakteri $S$. typhi.

Pertumbuhan koloni paling sedikit terdapat pada konsentrasi isolat Actinomycetes
$10^{-1}$. Konsentrasi isolat Actinomycetes $10^{-1}$ memiliki jumlah koloni rata-rata 30. Pertumbuhan koloni paling banyak terdapat pada kontrol negatif yaitu akuades. Kelompok kontrol negatif memiliki jumlah koloni tumbuh rata-rata 98,33 . Berdasarkan hasil pengamatan jumlah koloni terserbut, KBM isolat Actinomycetes terhadap pertumbuhan bakteri $S$. typhi tidak dapat ditentukan karena isolat Actinomycetes konsentrasi $10^{-1}$ pun belum dapat membunuh bakteri $S$. typhi yang ditandai dengan masih adanya koloni $S$. typhi yang tumbuh.

Tabel 3.Jumlah Koloni Salmonella typhi pada Media SSA dengan Waktu Inkubasi 24 Jam

\begin{tabular}{ccccccccc}
\hline \multicolumn{6}{c}{ Jumlah Koloni Salmonella typhi pada Media SSA dengan Waktu Inkubasi 24 Jam } \\
\hline Percobaan & $10^{-1}$ & $10^{-2}$ & $10^{-3}$ & $10^{-4}$ & $10^{-5}$ & $10^{-6}$ & Kontrol (+) & Kontrol (-) \\
\hline 1 & 29 & 49 & 60 & 71 & 80 & 92 & 0 & 95 \\
2 & 34 & 36 & 62 & 62 & 86 & 90 & 0 & 97 \\
3 & 27 & 39 & 55 & 67 & 78 & 81 & 0 & 103 \\
\hline Jumlah & 90 & 124 & 177 & 200 & 244 & 263 & 0 & 295 \\
\hline Rata-rata & 30,00 & 41,33 & 59 & 66,67 & 81,33 & 87,67 & 0,00 & 98,33 \\
\hline Std. Deviasi & 3,61 & 6,81 & 3,61 & 4,51 & 4,16 & 5,86 & 0,00 & 4,16
\end{tabular}

Pertumbuhan koloni dengan waktu inkubasi 48 jam paling sedikit terdapat pada konsentrasi isolat Actinomycetes $10^{-1}$ dengan jumlah koloni rata-rata 39,33, sementara kontrol negatif memiliki pertumbuhan koloni tumbuh paling banyak yaitu dengan jumlah koloni ratarata 112. Berdasarkan hasil pengamatan jumlah koloni tersebut, KBM isolat Actinomycetes terhadap pertumbuhan bakteri $S$. typhi dengan waktu inkubasi 48 jam juga tidak dapat ditentukan karena isolat Actinomycetes konsentrasi $10^{-1}$ pun belum dapat membunuh bakteri $S$. typhi yang ditandai dengan tidak adanya koloni tumbuh. 
Tabel 4. Jumlah Koloni Salmonella typhi pada Media SSA dengan Waktu Inkubasi 48 Jam

\begin{tabular}{ccccccccc}
\hline \multicolumn{6}{c}{ Jumlah Koloni Salmonella typhi pada Media SSA dengan Waktu Inkubasi 48 Jam } \\
\hline Percobaan & $10^{-1}$ & $10^{-2}$ & $10^{-3}$ & $10^{-4}$ & $10^{-5}$ & $10^{-6}$ & Kontrol (+) & Kontrol (-) \\
\hline 1 & 40 & 57 & 67 & 81 & 94 & 107 & 0 & 111 \\
2 & 42 & 45 & 68 & 69 & 101 & 102 & 0 & 109 \\
3 & 36 & 49 & 64 & 79 & 91 & 98 & 0 & 116 \\
\hline Jumlah & 118 & 151 & 199 & 229 & 286 & 307 & 0 & 336 \\
\hline Rata-rata & 39,33 & 50,33 & 66,33 & 76,33 & 95,33 & 102,33 & 0,00 & 112 \\
\hline Std. & \multirow{2}{*}{3,05} & 6,11 & 2,08 & 6,43 & 5,13 & 4,51 & 0,00 & 3,60 \\
Deviasi & & & & & & & & \multirow{2}{*}{6}
\end{tabular}

\section{Analisis data}

Nilai signifikansi uji One-Way ANOVA kelompok uji isolat Actinomycetes adalah 0,000 ( $\mathrm{p}<0,05$ ) sehingga dapat disimpulkan bahwa isolat Actinomycetes memiliki perbedaan aktivitas antibakteri terhadap pertumbuhan bakteri S. typhi pada masing-masing kelompok konsentrasi.

Hasil uji Post Hoc Bonferroni, hasil analisis dengan nilai signifikansi kurang dari $0,05(\mathrm{p}<0,05)$ yang artinya terdapat perbedaan bermakna antara kelompok. Perbedaan tidak bermakna didapatkan pada kelompok konsentrasi $10^{-1}$ dan $10^{-2}$ karena nilai signfikansi lebih dari $0,059(p>0,05)$

\section{PEMBAHASAN}

Penelitian ini menggunakan metode dilusi cair untuk menentukan nilai KHM lalu dilanjutkan penanaman pada cawan petri dengan media spesifik bakteri uji untuk menentukan nilai KBM dan menilai aktivitas antibakteri isolat Actinomycetes berdasarkan jumlah koloni S. typhi yang tumbuh. Perhitungan jumlah koloni $S$. typhi dilakukan pada waktu inkubasi 24 jam dan 48 jam. Pada penelitian ini, nilai KHM didapatkan pada konsentrasi isolat Acctinomycetes $10^{-2}$, mengingat tidak ada perbedaan aktivitas antibakteri yang bermakna antara konsentrasi isolat Actinomycetes $10^{-1}$ dan $10^{-2}$. Nilai KBM tidak dapat ditentukan. Namun, jumlah koloni rata-rata pada masing-masing kelompok uji mengalami peningkatan dari waktu inkubasi 24 jam ke waktu inkubasi 48 jam, yang menandakan aktivitas antibakteri isolat
Actinomycetes adalah menghambat pertumbuhan bakteri S. typhi atau bakteriostatik.

Penelitian Suryani dkk pada tahun 2014 menunjukkan hasil pengelompokkan aktivitas antibakteri isolat Actinomycetes terhadap bakteri Escherichia coli dan Salmonella typhi. Isolat Actinomycetes memiliki pengaruh terhadap pertumbuhan bakteri S. typhi [9]. Penelitian lain yang dilakukan oleh Aarthi dkk pada tahun 2020, mengisolasi Actinomycetes dari Hutan Mangrove Pichavaram, India, menunjukkan hasil empat dari 13 solat memiliki aktivitas antibakteri terhadap bakteri $S$. typhi [11]. Rai dkk pada tahun 2018, melakukan identifikasi dan pengukuran aktivitas antibakteri isolat Actinomycetes dari hutan, kebun, lahan pertanian, dan tepi sungai di Chitwan, Nepal.Hasil penelitian tersebut menunjukkan 13 dari 25 isolat memiliki aktivitas antibakteri terhadap bakteri S. typhi [12].

Terhambatnya pertumbuhan bakteri uji oleh isolat Actinomycetes diasumsikan akibat Actinomycetes memproduksi metabolit sekunder. Aktivitas senyawa antibakteri dari Actinomycetes terdapat dengan berbagai macam mekanisme. Mekanisme antibakteri tersebut antara lain adalah menghambat sintesis dinding sel bakteri, menghambat transkripsi dan translasi di ribosom, menghambat enzim DNA gyrase, dan menghambat sintesis DNA [13]. Actinomycetes memproduksi metabolit sekunder antara lain yaitu laktam yang menghambat sinstesis dinding sel bakteri, aminokumarin yang menghambat hidrolisis ATP, peptida yang menghambat biosintesis protein pada fase 
translasi, dan kibdelomycin yang menghambat aktivitas enzim DNA gyrase [14].

S. typhi merupakan bakteri Gram negatif. Pada umumnya bakteri Gram negatif mempunyai ketahanan terhadap zat antibakteri yang kuat. Hal tersebut terjadi mungkin karena selubung sel bakteri Gram negatif sangat kompleks dengan struktur berlapis-lapis [5]. Struktur dinding sel bakteri S. typhi terdiri dari lapisan lipopolisakarida dan peptidoglikan sehingga memungkinkan bakteri $S$. typhi memiliki ketahanan yang lebih baik terhadap zat antibakteri. Dinding sel yang kompleks tersebut dapat menghalangi senyawa antibakteri untuk menembus ke dalam membran sel S. typhi [15].

Hasil uji aktivitas antibakteri isolat Actinomycetes dengan metode SPC menunjukkan adanya aktivitas antibakteri terhadap pertumbuhan bakteri $S$. typhi. Hal tersebut dibuktikan dengan adanya peningkatan jumlah koloni tumbuh seiring dengan meningkatnya pengenceran isolat Actinomycetes. Peningkatan jumlah koloni tumbuh seiring dengan meningkatnya pengenceran isolat Actinomycetes terjadi karena semakin rendah konsentrasi substansi uji, maka semakin rendah juga konsentrasi zat antibakteri aktif di dalamnya. Aktivitas antibakteri isolat Actinomycetes adalah menghambat pertumbuhan bakteri $S$. typhi. Hal tersebut dibuktikan dengan meningkatnya jumlah koloni rata-rata $S$. typhi dari waktu inkubasi 24 jam ke waktu inkubasi 48 jam.

\section{KESIMPULAN}

Berdasarkan hasil analisis data dan pembahasan yang telah dilakukan pada penelitian ini, didapatkan kesimpulan sebagai berikut yaitu terdapat potensi antibakteri isolat Actinomycetes yang bersifat bakteriostatik terhadap pertumbuhan bakteri Salmonella typhi.

\section{DAFTAR PUSTAKA}

[1] CDC. 2012. 'The National Center for Emerging and Zoonotic Infectious'.

[2] Widodo, D. 2009. Demam tifoid. Buku Ajar Ilmu Penyakit Dalam Edisi Ke-5. 2797806.
[3] Crump, J. A., Sjölund-Karlsson, M., Gordon, M. A., \& Parry, C. M. 2016. Epidemiology, Clinical Presentation, Laboratory Diagnosis, Antimicrobial Resistance, And Antimicrobial Management Of Invasive Salmonella Infections. Clinical Microbiology Reviews.

[4] Id, C. D. B. et al.2018. A systematic review of antimicrobial resistance in Salmonella enterica serovar Typhi, the etiological agent of typhoid. pp. 1-15.

[5] Jawetz, E., Melnick, J., Adelberg, E. AndCarroll, K., 2016. Jawetz, Melnick, \& Adelberg's Medical Microbiology. 27th ed. New York: McGraw-Hill Education.

[6] Valli S, et al. 2012. Antimicrobial potential of Actinomycetes species isolated from marine environment. Asian Pac J Trop Biomed; 2:469-73.

[7] Charousová, I., Medo, J., Halenárová, E., \& Javoreková, S. 2017. Antimicrobial and enzymatic activity of actinomycetes isolated from soils of coastal islands. Journal of advanced pharmaceutical technology \& research, 8(2), 46-51. https://doi.org/10.4103/japtr.JAPTR_161_1 6

[8] Bahar, M. and Zulfa, F. 2018. Potention of Antibacterial Isolat Actinomycetes to Proteolitic and Amilolitic Activity Escherichia Coli ATTC 25922, Jurnal Teknologi Laboratorium. Poltekkes Kemenkes Yogyakarta, 7(1), p. 25. doi: 10.29238/teknolabjournal.v7i1.101.

[9] Pratiwi, T. A. (no date) 'DARI SAMPEL TANAH KEBUN RAYA BOGOR TERHADAP BAKTERI Staphylococcus aureus ATCC 25923 SECARA IN Effectiveness Antibacterial Test of Actinomycetes Isolate From Soil From Bogor Botanical Garden Against Staphylococcus aureus ATCC 25923 by In Vitro'.

[10] Suryani, S. et al. 2014. Seleksi dan Uji Antibakteri Aktinomisetes Asal Tanah Gambut Rimbo Panjang Kampar Riau Terhadap Escherichia coli dan Salmonella typhi', JOM FMIPA. 
[11] Uji Aktivitas Isolat Actinomycetes Dari Tanah Sawah Sebagai Penghasil Antibiotik Naskah Publikasi Oleh: Fatah Miftakul Jannah K 100090148 Fakultas Farmasi Universitas Muhammadiyah Surakarta Surakarta 2013 (No Date).

[12] Aarthi, M., Kamalanathan, D. and Balakrishnan, V. 2020. Isolation Of Actinomycetes From The Sediments Of Pichavaram Mangrove Forest, South India And Analysing Their Antibacterial Efficacy. 13(4).

[13] Rai, K., Khadka, S. and Shrestha, B. 2018. Actinomycetes : Isolation, Characterization and Screening for Antimicrobial Activity from Different Sites of Chitwan , Nepal, 3(1), pp. 25-30. doi: 10.11648/j.ijmb.20180301.14.

[14] Brooks, G. F., Jawetz, E., Melnick, J. L., \& Adelberg, E. A. 2010. Jawetz, Melnick, \& Adelberg's medical microbiology. New York, McGraw Hill Medical.

[15] Jakubiec-Krzesniak, K. et al.2018. Secondary metabolites of actinomycetes and their antibacterial, antifungal and antiviral properties', Polish Journal of Microbiology, 67(3), pp. 259-272. doi: 10.21307/pjm-2018-048.

[16] Nanasombat S, Phunpruch S, Jsichslsd T. 2012. Screening and identification of lactic acid bacteria from raw seafoods and Thai fermented seafoods products for their potential use as starter cultures. Songklanakarin Journal of Science and Technology 34 (3): 255-262. 